The Invention of Trauma in German Romanticism

Author(s): Fritz Breithaupt

Source: Critical Inquiry, Vol. 32, No. 1 (Autumn 2005), pp. 77-101

Published by: The University of Chicago Press

Stable URL: http://www.jstor.org/stable/10.1086/498005

Accessed: 13-06-2017 15:54 UTC

JSTOR is a not-for-profit service that helps scholars, researchers, and students discover, use, and build upon a wide range of content in a trusted digital archive. We use information technology and tools to increase productivity and facilitate new forms of scholarship. For more information about JSTOR, please contact support@jstor.org.

Your use of the JSTOR archive indicates your acceptance of the Terms \& Conditions of Use, available at http://about.jstor.org/terms

The University of Chicago Press is collaborating with JSTOR to digitize, preserve and extend access to Critical Inquiry 


\title{
The Invention of Trauma in German Romanticism
}

\author{
Fritz Breithaupt
}

What is the promise of trauma? Or, why was the concept of trauma invented? Which constellations of discourse made such an invention or discovery desirable, useable, or at least understandable? And, what are the consequences of the formulation of a new idea, such as that of trauma?

The following text traces how the concept of trauma emerged as a response to a certain understanding of the self in romanticism. The new notion of self and selfhood is dated to the years around 1770, at least within the English, French, and German contexts. ${ }^{1}$ Prior to 1770 selfhood seems not to have been a general concern (unlike notions of identity and belonging). However, around and after 1770 selfhood becomes a prerequisite for the modern man. ${ }^{2}$ In fact, the very notion of le moi or das Ich gains sudden and rapid popularity in just a few years. While there are some common-

This essay has benefited from many readers and listeners, including graduate students in a course on trauma in fall 2001 and the participants of the first annual Bloomington EighteenthCentury Studies Workshop in May 2002, as well as audiences at lectures in the German departments at New York University, Johns Hopkins University, and Princeton University. In particular, I would like to thank Michel Chaouli, Elliott Schreiber, and Dror Wahrman for their rich criticism and ideas.

1. For the English context, see Dror Wahrman, The Making of the Modern Self: Identity and Culture in Eighteenth-Century Britain (New Haven, Conn., 2004), and Deidre Shauna Lynch, The Economy of Character: Novels, Market Culture, and the Business of Inner Meaning (Chicago, 1998). For a three-step development of notions of selfhood in France between 1700, 1770, and the early 18oos, see Jan Goldstein, "Mutations of the Self in the Old Regime and Postrevolutionary France: From Ame to Moi to Le Moi," in Biographies of Scientific Objects, ed. Lorraine Daston (Chicago, 2000), pp. 86-117. For the German context, see Fritz Breithaupt, "Goethe and the Ego," Goethe Yearbook 11 (2002): 77-109.

2. For the implications of this transition, see the foundational text by Niklas Luhmann, "Individuum, Individualität, Individualismus," Gesellschaftsstruktur und Semantik, 4 vols. (Frankfurt, 1989), 3:149-258. 
alities between the developments in these countries, the German period of Sturm und Drang radicalizes the notion of selfhood to such a degree that the battle cry for the self in this period turns into a lamentation about its unachievability. Instead of celebrating their genius, originality, singularity, or autonomy, the Germans only recognize that they cannot meet the demand set by the notion of das Ich. Thus, instead of gaining a self, the German romantics suffer from their perceived weakness in failing to accomplish the creation of a self. In short, the self exists as self-compulsion (Ich-Zwang).

This article examines how it is in this context that the idea of trauma comes about as a possible remedy for the impossibility of the self. Trauma is invented where it is needed, where it holds a promise. This promise, as we will see, is the promise to turn weakness into strength, to turn the weakness of not having a self into the very self that is sought. This may also explain the sudden emergence of childhood as the model of selfhood in the late eighteenth century; the child's weakness and absolute reliance on the outside turns out to be the condition of possibility for selfhood. ${ }^{3}$ Insofar as trauma responds to the promise of strength, it is not governed by the authenticity of one's experiences. Hence the simulation of trauma, for example by constructing false accounts of abuse, is not an accident, but part of its structure.

The proposed origin of trauma may explain what otherwise would be hard to explain when we look back at the history of the idea of trauma from a point in time after two world wars and after the Holocaust (and yet without being beyond it); trauma was not an easy condition to detect. Apparently, the suffering of trauma is not available for direct observation. It is striking, for example, how little empathy early psychologists had for traumatized veterans of the Napoleonic wars. ${ }^{4}$ The psychologists of the time

3. In the past decade, several scholars have added to Charles Taylor's insight that the model for the self and its interiority since the eighteenth century was the figure of the child; see Charles Taylor, Sources of the Self: The Making of the Modern Identity (Cambridge, Mass., 1989); Carolyn Steedman, Strange Dislocations: Childhood and the Idea of Human Interiority, 1780-1930 (Cambridge, Mass., 1995); Larry Wolff, "When I Imagine a Child: The Idea of Childhood and the Philosophy of Memory in the Enlightenment," Eighteenth-Century Studies 31 (Summer 1998): 377401; and Adriana S. Bezanquén, "Childhood, Identity, and Human Science in the Enlightenment," History Workshop Journal 57 (Spring 2004): 35-57.

4. The soldiers usually only figure as icons of empathy when they allegorize a nation's loss; see John Richard Watson, Romanticism and War: A Study of British Romantic Period Writers and the Napoleonic Wars (Houndsmill, 2003), pp. 23-38.

Frit Z BREITHAUPT (fbreitha@indiana.edu) is associate professor of Germanic studies and director of West European studies at Indiana University. He is author of a book on Goethe, Jenseits der Bilder: Goethes Politik der Wahrnehmung (2000), and the forthcoming study The Ego-Effect of Money. 
tended to attribute the "anxiety" or "stupidity" of shell-shocked soldiers to a deficient upbringing that supposedly failed to provide them with the stability and strength they needed. According to these accounts, war only brought to the surface what was already present-or more precisely, not present—within the soldiers: masculinity. And war, in this psychological sense, was perceived as a nonevent because it did not change the soldiers in a significant way but only brought their weak, melancholic inner constitutions to the surface. ${ }^{5}$ In a similar way, the French institution meant to study selfhood—-the Society of Observers of Man (Sociéte des Observateurs de l'Homme)—completely failed to take trauma into consideration when it examined the famous wild boy from Aveyron. Instead of considering that the harsh conditions of the abandoned child's years in the forest might have traumatized the child, most of its members declared the child to have been born stupid and thus uneducateable. ${ }^{6}$

The understanding of trauma does not come from a mode of direct and immediate observation. Instead of tracing empirical data around 1800, the following essay pursues the promise inherent in trauma as revealed by early texts within German romanticism. Certainly, phenomena of trauma are witnessed in many places during the age of romanticism as well (one need only consider Ann Radcliffe's The Romance of the Forest or Wordsworth's The Thorn and The Prelude). ${ }^{7}$ However, as far as I can see, the drive towards a conceptual and therefore operative understanding of what we now would call trauma took place within the new German and Austrian literature of empirical psychology. ${ }^{8}$

Empirical psychology comes about and begins to shape a discourse of its own at the junction of two seemingly opposite forces: a positive reevaluation of the impact of memory and the acknowledgment that memory is

5. It was already an advance when Dominique Larrey, a military surgeon in Napoleon's army, described what we would call shell shock as a form of insanity; see Anthony Babington, ShellShock: A History of the Changing Attitudes to War Neurosis (London, 1997), p. 8. For the assumption of a male hysteria in nineteenth-century shell-shock psychiatry, see Elaine Showalter, The Female Malady: Women, Madness, and English Culture, 1830-1980 (London, 1985), p. 172.

6. Trauma simply did not fit into the picture of the observateurs because they remained fixated on the perfectibility of man; see Bezanquén, "Childhood, Identity, and Human Science in the Enlightenment."

7. On Radcliffe's text, see Elisabeth Bronfen, The Knotted Subject: Hysteria and Its Discontents (Princeton, N.J., 1998). On Wordsworth and the wounds of memory, see Aleida Assmann, Erinnerungsräume: Formen und Wandlungen des kulturellen Gedächtnisses (Munich, 1999), pp. 89-113.

8. In effect, this study suggests that the origin of the concept of trauma should be located considerably earlier than Ruth Leys does in her rich and complex account of the history of the clinical notion of trauma. In fact, the early history of the notion of trauma leads more directly to Freud's later work on trauma than to the British empirical doctors' discovery of the shock condition; see Ruth Leys, Trauma: A Genealogy (Chicago, 2000). 
subject to literary fictionalization. ${ }^{9}$ Memory becomes suspect or, put positively, productive. It is at this junction of memory and fictionalization that the psychological speculations of Locke, Hume, Condillac, and Herder, which centered on identity and stability (even if skeptically as in Hume), ${ }^{10}$ give way to a new mode that blends self-observation, self-fashioning, and self-experimentation. ${ }^{11}$ Fictionalization and thus literature are an essential component of this new discipline of the 1780 os and 1790s, as evidenced by Karl Philipp Moritz, the father of modern psychology, who edited and collected many life stories to produce psychological accounts of them and who wrote the first "psychological novel," which attempts to synthesize these accounts by observing his own past as if he were running an experiment. And again, as we will see, within this experiment lies a hope, a promise.

There are three basic arguments that structure this paper: (1) In its initial foundation, empirical psychology is less a science for understanding the human mind than a technique for transforming human beings-specifically, for transforming human weakness into human strength. (2) The birth of modern psychology is intimately linked with the production of its object, namely, the self. More specifically, empirical psychology is first of all a technology for producing (a specific) self that could become the object of an empirical science. In its basic structure, this self is an institution that grants selfsameness to itself and its acts. (3) The institutionalization of the self relies on memory, which allows both the repetition and the reversal of the past. It is by means of memory that the wounds of the past, if they have not succeeded in killing the individual, can become the most important assets of the self. In this sense, trauma is the condition of possibility for the self. As we will see, eighteenth-century psychology was still able to view trauma as a positive possibility for transformation, whereas later psychology increasingly views trauma as a place without escape-the self as a prison. In this paper, the witness for "positive trauma" is Moritz. E. T. A. Hoffmann is the witness for the prison of repetition compulsion (Wiederholungszwang). Honoré de Balzac leads us to consider the cure for trauma. In

9. As Larry Wolff put it: "On the one hand, the empirical psychology pioneered by John Locke, and developed by David Hume and the abbé de Condillac in the eighteenth century, produced a radical reevaluation of memory, in its relation to perception and experience. On the other hand, the revolutionary modern art of autobiography, as inaugurated by Rousseau's Confessions, authorized an altogether new deployment of the art of memory in the service of literary selffashioning" (Wolff, "When I Imagine a Child," p. 378).

10. Locke is, of course, the first to bind the fate of the self's identity to memory. Hume could be seen as the first skeptic. See Taylor, Sources of the Self, pp. 143-76.

11. See Stuart Walker Strickland, "The Ideology of Self-Knowledge and the Practice of SelfExperimentation," Eighteenth-Century Studies 31 (Summer 1998): 453-71. 
conclusion, we will reflect upon what has come to be known in recent decades as trauma studies.

\section{Psychology as a Technology of Reversal}

The story that is often told about the birth of empirical psychology in the late eighteenth century goes as follows: Once upon a time, there was a smart but poor fellow, a pauper in a world full of princes. He was the middle-class man. And because he lacked the wealth and nobility of the aristocrats, he staked his claim in the world vis-à-vis the privileged class by means of his intellect, telling stories of his weakness and misery, until all began to listen to his tales of woe. Ranging from mere sensibility to idiosyncrasy and from anxiety to the pathological, it was the psychological that manifested the presence of this new man. And then, surprisingly, this new man's weakness, with which he presented his privacy to the public, turned out to be his advantage. The new man claimed that his weaknesses made him more human and more humane and thus better able to make intelligent choices, resist bad influences, be more responsible than others, and thus, ultimately, to be stronger. And everyone started to believe in the new middle-class man (and woman, too, for she is weak and human as well). ${ }^{12}$

The cloudy spot at the core of this story, namely the transformation of the weak man into the strong man, is found in most stories that deal with the rise of the middle-class man. How can self-confidence, as well as outside recognition, emerge from a state of weakness? Not only have later scholars recognized this cloudy spot, but eighteenth-century thinkers themselves provided an array of techniques of reversal that would make such a rise of the weak plausible. It would not be far off the mark to characterize the eighteenth century in terms of its obsession with technologies of reversal, ranging from theories and practices of political revolution to the countless eighteenth-century tragedies in which the dying heroes are celebrated as winners, ${ }^{13}$ from Pietist conversions, where the confessing sinner is uplifted into grace, to fantasies about female leadership in the Amazon state.

At its beginning, the psychological is nothing but a call for reversal. That is, the notion of the psychological as a whole comes about as the recipient of the demand to give a shape, a recognizable form to a process of an individual's reversal. However, as a technology of reversal, the psychological

12. See Jürgen Habermas, The Structural Transformation of the Public Sphere: An Inquiry into a Category of Bourgeois Society, trans. Thomas Burger and Frederick Lawrence (Cambridge, Mass., 1989).

13. Schiller, Schelling, and Hegel have developed this logic to its perfection; see the famous account by Phillippe Lacoue-Labarthe, Typography: Mimesis, Philosophy, Politics, ed. Christopher Fynsk (Cambridge, Mass., 1989), pp. 208-35. 
is a bad starting point insofar as it has no preexisting tools or devices at hand to bring about the reversal. All it relies on is recollection. As long as recollection is seen to be a mere storage of memory material, it appears to be unfit to destabilize the division between "weakness" and "strength." Instead, the psychological needs an act that, while recalling and repeating the past as it was, reenacts it, gives it space and time, and thus repeats it as something different. As Derrida would say, the psychological requires an archive. ${ }^{14}$

In fact, during the last third of the eighteenth century the understanding of memory rapidly changes, making memory the precursor of the unconscious. Whereas the first Encyclopedia Britannica from 1771 still describes memory as the "store-house of our ideas" whose sole task is to recall past perceptions in the absence of the sensual object, the new and mostly continental thought of the time expands the role of memory dramatically. ${ }^{15}$ From a mere ability to recite, memory becomes a sleeping giant that can be awakened and take over a person, trigger thoughts and actions uncontrolled by the conscious mind. ${ }^{16}$ (In fact, the very distinction between thought and action crumbles simultaneously, which leads, for example, to new legal codifications of the bad intention.) States of dreaming, of temporary dislocation of the self, and of hypnosis are evidence of the power of memory and the unconscious. Mesmer becomes a European phenomenon with his exploitation of the uncontrolled states of the mind.

However, more far-reaching than the hypnotists à la Mesmer are those conceptualizations around 1800 that deal with the apparatus of selfobservation. To observe one's past means first of all to frame the past within an observatory, within some stable structure from which the past can be monitored, repeated, tested. ${ }^{17}$ What the new empirical psychology adds to Locke's accounts of selfhood and repetition is the peculiar insight into the productiveness of self-observation. The stable frame, observatory, or laboratory does not precede observation but rather comes about in the very act of repeating, recalling. By observing one's past, one supposes or claims that there is a stable frame that permits observation, some supertemporal

14. See Jacques Derrida, Archive Fever: A Freudian Impression, trans. Eric Prenowitz (Chicago, 1996).

15. Encyclopedia Britannica, or a Dictionary of Arts and Sciences, Compiled upon a New Plan (Edinburgh, 1771), s.v. "metaphysics," p. 178. See also Douwe Draaisma, Metaphors of Memory: A History of Ideas about the Mind, trans. Paul Vincent (Cambridge, 2000), pp. 68-83.

16. For a rich body of material dealing with the new interest in dreams and dislocations of the self, see Doris Kaufmann, "Dreams and Self-Consciousness: Mapping the Mind in the Late Eighteenth and Early Nineteenth Centuries," in Biographies of Scientific Objects, pp. 67-86.

17. On the logic of testing, see Avital Ronell, "Proving Grounds: On Nietzsche and the Test Drive," Modern Language Notes 118 (Apr. 2003): 653-69. 
stability. This supposed (or simulated) supertemporal stability is "the self." 18

When Moritz announced in 1782 what would become the foundational journal of empirical psychology, Das Journal zur Erfahrungsseelenkunde, he attested to the duality of self-observation as both scientific observation and as the production of a stability that was previously unknown to the self. He argues that self-observation is distinct from other forms of observation because the observation of one's self and grief establishes a "refuge" from which the observation takes place. ${ }^{19}$ By being observed and thus repeated, grief ceases to be grief because the repetition itself provided a stable refuge.

It is here that "strength" enters into the picture: the strength of the laboratory, the observation, and therefore the strength of the observer, the self, that (strongly) guards the identity of its (weak) past. In other words, the act of repetition implies both the weakness of the original event and the strength, stability, or frame from which it can be observed, repeated, and recalled. This is the key achievement of empirical psychology: to establish an institution of the self that can monitor the past, repeat it, and thereby turn the past wounding and weakening into a strength, insofar as these wounds offer the opportunity (or necessity) to repeat and thus to set up a stable frame for the very repetition.

To recollect and to repeat is to frame what is repeated in the blinders of observation. To repeat entails three things: first, to repeat an old act, which thereby, secondly, creates a stable frame that allows for repetition in order for, thirdly, the old act to be reversed on the basis of the newly created stability. Whatever the old act was, as a repeated act it is a stabilizing act.

\section{Pedagogy before the Self}

In the beginning, there was pedagogy. At least this is how the middleclass man wishes his story to be told because aristocracy is determined by birth alone. It is, therefore, not surprising that (mostly middle-class) eighteenth-century thinkers stress the impact of education, upbringing, influences, and affect upon one's abilities and identity-formation. These influences take the form of friends, milieu, reading materials, images, examples, behavioral models, tales of wet nurses, and the like. The new ped-

18. This vocabulary was used by Kant to describe historical observation; one can only observe and thus repeat from a position outside of time, a stable frame, within which the past could be viewed in its changeability. "All determination of time presupposes something permanent [Beharrliche] in perception." While Kant insists that this "permanent cannot, however, be something in me," the early psychologists will institutionalize the self as something permanent (Immanuel Kant, Critique of Pure Reason, trans. Norman Kemp Smith [New York, 1965], p. 245).

19. See Karl Philipp Moritz, "Vorschlag," Deutsches Museum 1 (1782): 492-95. See also Moritz, "Das menschliche Elend,” Werke, ed. Horst Günther, 3 vols. (Frankfurt, 1981), 3: 210-14. 
agogy reinvents the child as its subject. The premise of the "pedagogical century" is that it views the young individual largely as a tabula rasa, an unshaped entity that not only can be edified but needs learning to be anything at all. (This new entity of the child has more than a few similarities with the utopian island; it marks a beginning, open for Enlightenment speculation.) The precondition of the assumed perfectibility of man is that he is "affectable" by the environment. One could say that affectability is the essence of the new pedagogical man.

However-and here one comes to the structural demands of these bourgeois ideas-the affectability of man is also the precise limit of this pedagogical vision. Because man is thought to be essentially affectable, the one thing pedagogy fails to explain is how man could learn to be nonaffectable, that is, strong, independent, and solid, having a clear identity and having, to use the eighteenth-century term, character. But this was the project of pedagogy in the eighteenth century: to raise strong and independent individuals who could also go against the grain of their time and withstand its influences, so that every household leader can be compared to a sovereign or noble statesman. ${ }^{20}$ But how can a discipline of influence bring about an end to influence?

Pedagogy offered a model of identity derived from the intensive discussions surrounding childhood that followed the publication of Rousseau's Émile, ou de l'education and led to the modern, child-centered pedagogies of Johann Bernhard Basedow, Dietrich Tiedemann, Christian GotthilfSalzmann, Joachim Heinrich Campe, Johann Heinrich Pestalozzi, and so on. One of the most widely read and influential pedagogues of the age, Campe, writes:

When you, good mothers, imagine the young soul of a newborn child as an extremely soft mound of wax, which still preserves even the gentlest touch, then, you are ... on your way to gaining a fine image of the soul. ... The soul differs from all things in that the impressions it receives can by no force be neutralized or destroyed, and can only be modified by later impressions. This is different for an actual mound of wax that, with little effort, can always be changed and destroyed so that no trace remains of the impression.... Imagine that there were certain colors of an infinite variety which could not, once they were painted, be removed, scratched away or painted over in such a way that they could not still shine through. Imagine now further that all sensual objects in

20. Enlightenment thinkers from Locke to Lessing stress the need for the individual—especially the father- to be a sovereign. See Wilfried Wilms, "Im Griff des Politischen: Konfliktfähigkeit und Vaterwerdung in Emilia Galotti," Deutsche Vierteljahrsschrift für Literaturwissenschaft und Geistesgeschichte 76 (Mar. 2002): 50-73. 
the world (that is, everything that can be seen, heard, smelled, tasted, and felt) were equipped with a brush dipped into such colors such that they would without interruption paint all things which come into their proximity. Imagine now that a white board were placed among these objects with brushes. And, watch, what would happen? You would find that the surface of the board would change its appearance in every moment, while, however, no stroke of the brush ... would ever be lost completely.... Every sensual object close enough to your child to impress the sensual apparatus awakens an image, a representation in the soul. This image is only fleeting and will be suppressed [verdrängt] within the dark consciousness of the child by other images and representations. However, do not think that it [the image] will be wasted for the little soul or will remain without consequences. ${ }^{21}$

According to Campe and other pedagogues, the essence of identity is its affectability. It is mutable over time and thus is not to be considered a static monument. This can be formulated as follows: First, identity is acquired; it is not given a priori. Second, this acquisition takes place by means of contact with the outside world. Third, the key force in identity making is perception, a process that according to Campe seems to be more passive than active (it is the objects that paint the soul). Fourth, because perception is the force driving identity-formation, identity is subject to permanent change. Even the figure that Campe sets as the goal of education and development changes its surface and color constantly and is in danger of being destroyed by a single (sensual) blow. Fifth, identity is radically unique; no two individuals are alike. Finally, identity is cumulative, nothing gets lost. In short, the individual starts out as a more or less empty entity without yet having an identity. It acquires an identity only through constant exposure to external impressions. Each and every impression from the outside has the potential to destroy the figure. However, without these sensual impressions there would be no identity as such, but rather an uninscribed surface, a mere heap of unshaped wax.

One should note briefly that these specifications have far-reaching consequences for modern pedagogy, many of which were already drawn by Campe, Basedow, and Pestalozzi. To mention just two: First, it is best to leave a child with as little outside guidance and force as possible because every impulse, whether with positive or negative intentions, will impress itself on the child mainly as "force" or "violence."22 Second, Pestalozzi as-

21. Joachim Heinrich Campe, Über die früheste Bildung junger Kinderseelen, ed. Brigitte H. E. Nestroj (1787; Frankfurt, 1985), pp. 81-82.

22. Johann Bernhard Basedow, for example, explains how an early and strict education forced upon pupils plants seeds of unwillingness so that the benefits of education are overwhelmed by the negative effects of these planted seeds. "Wenn ein Kind bey dem, was zur Religion gehört, lesen, schreiben und memorieren lernt, und oft für Nachlässigkeit oder Zerstreuung gezüchtigt wird; so 
sumes some equilibrium of forces where every outside force on the soul will ultimately need to find some inside relief. That is, every dent the wax receives from the outside will result in a bump somewhere else. ${ }^{23}$ However, we will be more concerned in the following with the implications of these specifications than with the consequences.

Even though these pedagogues stress the desirability of stable human identities, they cannot account for their genesis. It is the failure of pedagogy to offer a model for explaining the reversal from the affectable to the strong man that called for a new intellectual site, a new discourse, a new thought machine. And it is within this very gap between the perfectible, affectable man and the strong, unaffectable man that the psychological will nest to provide the operation that closes the gap.

\section{Moritz and the Reversal of Recollection}

At first, it seems that Moritz-hailed nowadays not only as the philosophical inventor of the autonomy of art but also of empirical psychologyfollows in Campe's footsteps because he stresses the long-term effects of early impressions on later development and identity. In particular, Moritz emphasizes how one's cognitive understanding of self and world can be traced back to certain impressions and associations from one's past andlike Tiedemann ${ }^{24}$ —concludes that these impressions are the individual's only resource for organizing his or her worldview.

However, Moritz shifts the perspective from the moment of the impression itself to a later time when the impression is remembered. Moritz thereby adds another force to this model of identity-formation by means of impressions-retrospection. Whereas Campe and Pestalozzi, by employing the imagery of the painter or sculptor, implicitly emphasize the strongest impression as the most decisive factor in identity-formation, Moritz uses a more complex criterion to determine which impressions matter most - those that are later remembered. Two questions need to be raised: (1) What kind of impressions are later remembered? (2) What does the later recollection do with these impressions, which turn out to be so decisive for one's identity?

hat man den Samen eines künftigen Widerwillens gegen solche Worte und Sätze in den Gemüthern ausgestreuet. Dieser Saame wächst auf" (Johann Bernhard Basedow, Methodischer Unterricht der Jugend in der Religion und Sittenlehre der Vernunft nach dem in der Philalethie angegebenen Plane [Altona, 1764], p. viii).

23. See Johann Heinrich Pestalozzi, "Tagebuch Pestalozzis über die Erziehung seines Sohnes" (1774), Werke, ed. Gertrude Cepl-Kaufmann and Manfred Windfuhr, 2 vols. (Munich, 1977), 2:7-18.

24. See Dietrich Tiedemann, Beobachtungen über die Entwickelung der Seelenfähigkeiten bei Kindern (1787; Altenburg, 1897). 
Moritz offers an account of what makes recollections so significant in his own childhood memories, which he repeatedly recounts in factual and fictional discourse. These different recollections have been subjected to a significant amount of recent debate concerning their precise meaning and significance. ${ }^{25} \mathrm{My}$ argument in regard to these recollections is simply that most and, in fact, all but one (a meaningful exception) ${ }^{26}$ of these recollections include some "false idea," some misguided association, some perception or some interpretation of a situation that is wrong - at least in the eyes of the one who later remembers and evaluates these impressions, events, and situations. Recollection is possible because there is something left to be done for a critical memory, something to reconsider and reevaluate. These false ideas are usually sensual ideas, or perceptions, but also include ideas of cause and effect or moral ideas.

In "Erinnerungen aus den frühesten Jahren der Kindheit" (Memories from the Earliest Years of My Childhood) (1783), Moritz recalls a huge closet from his childhood precisely because, as a child, he thought it must be inhabited by people: "I also remember a black closet on the floor of a neighbor's house in the town of my birth, and this closet seemed so uncannily large to me that I believed that there had to be people living inside." ${ }^{27}$ In several other memories, Moritz emphasizes, and actually italicizes, the color given in the memory, a color that is linked to a false idea. He remembers the dress of his family's "mean, hard" landlady to be "gray" ("E," p. 67). That is, the first association with gray is that of meanness or hardness. Yet, as strongly as this first impression of the color gray probably was felt, the color association ought to prove itself to be misleading over time. Not every woman wearing gray will show similar character features.

The early impression needs to be adjusted. In the same text, he remem-

25. See Anthony Krupp, "Other Relations: The Pre-History of le moi and das Ich in Jean-Jacques Rousseau, Karl Philipp Moritz, and Johann Gottlieb Fichte,” Goethe Yearbook 11 (2002): 111-31; Elliott Schreiber "Pressing Matters: Karl Philipp Moritz's Models of the Self in the Magazin zur Erfahrungsseelenkunde," Goethe Yearbook 11 (2002): 133-58; Andreas Gailus, "A Case of Individuality: Karl Philipp Moritz and the Magazine for Empirical Psychology," New German Critique 79 (Winter 2000): 67-105; and Erich Meuthen, Selbstüberredung: Rhetorik und Roman im 18. Jahrhundert (Freiburg, 1994), pp. 234-40.

26. The single childhood recollection that Moritz repeatedly reports—under the guise of his pseudonym Anton Reiser - that does not hinge on a correctable, revisable false idea is a memory of being under the cover of his mother's coat so that the harsh weather did not affect him. In all accounts of Moritz's early memories, this event appears as the first one. It becomes the model for the act of recollecting because it indicates where recollection should end, namely, in a state of being unaffectable, covered up by his mother. It is the first memory that is not to be corrected and thus does not allow the transformation from weak to strong.

27. Moritz, "Erinnerungen aus den frühesten Jahren der Kindheit," Gnothi Sauton: Magazin zur Erfahrungsseelenkunde 1, no. 1 (1783): 67; hereafter abbreviated "E." See also Moritz, Werke, 3:104-7. 
bers how the landscape seemed to be "flying by" while he was sitting on a moving chariot ("E," p. 69). In all of these cases, some perception or interpretation of a situation gives birth to an idea that is later proven to be wrong. It seems that it is precisely the false idea that keeps the past available for later thought. A more complex account of such a false idea is presented in the following scene from Moritz's childhood:

I ran across the street from our house ... and back again. A well-dressed man walked in the middle of the road and I ran straight into him. Now I clearly recall how I started to hit the man with both fists because I thought he had done me an injustice, whereas, in fact, I was the wrongdoer [da ich doch im Grunde der beleidigende Teil war]. [“E," p. 68]

In this recollection, the false idea is moralistic, an incorrect perception of who is right and wrong. Here the correction of the past does not affect a wrong perception as in the earlier hallucinations but a perception of something that is wrong and should be changed. Thus, it is again the false idea that makes the event memorable because Moritz later feels compelled to admit that it was he who was wrong, not the stranger. The recollection of the event is thus a correction, a correction in which Moritz himself was the offender and not the offended as he had thought. This correction shifts the agency to Moritz in at least three ways: He was the perpetrator of injustice and not the victim; he is the one who needs to retell the story in order to correct his original, mistaken perception; and, as the agent, he is the one who still needs to apologize.

Moritz publishes this account again in 1785 in the first part of the more or less autobiographical novel Anton Reiser. He makes a remarkable addendum to the scene by writing that he had already had the feeling that he was doing something wrong at the time of the event and that he pushed the man "violently, because he wished to persuade himself and others that he had been wronged, although he had an inward feeling that he himself was the offender." ${ }^{28}$ Here, the order of perception and correction is reversed. Whereas the first account of the memory simply shows a false perception of the situation that requires a later correction, the second memory shows a correction that aims to alter the simultaneous perception of the event. He does not want his being wrong, which he knows to be true, to be perceivable. This is remarkable in two respects. First, correction is not a secondary phenomenon to the perception of reality, but rather a forming principle of perception. Reiser pushes the man "because" he does not want to admit what happened. Second, this refusal to admit indicates that the false idea that 
allows, and calls for, a later revision is not simply a mistake. Rather, a false idea or memory is the product of an active and violent repression of the truth. The event lasts as a memory as long as the revision and correction is kept at bay violently, if necessary, by means of fists. Only when the later recollection reverses the primal/original event does it come to an end.

To summarize: The retrospections Moritz reports require or invite a correction, revision, alteration, or perhaps taming of what the child seemed to experience, despite what actually happened. This emphasis on the perspective of retrospection is the key distinction between the pedagogical and the new psychological discourses. Pedagogy examines events as they take place; psychology deals with those past events that retrospectively matter (even if they did not while they occurred). Moritz's point is not only that one remembers those moments that allow or call for a later alteration but that early impressions matter insofar as they call for a second force to revise them. In revising the past impressions, they are affirmed as the proper space of the self (because it matters that they need to be revised) precisely because they are not (yet) proper. It is no coincidence that Moritz emphasizes the role of phenomena and language (homophones, alliterations, and so on) in these false ideas, as they allow the distinction to be made between the mere deceptive will-o'-the-wisp and the appearance of a truth, thus opening a space in which corrective revisions can take place.

One could say with Niklas Luhmann that false ideas are the medium of the psychological. As a medium, the false ideas bring together, and also hold apart, two distinct entities, namely, the recollected past and the present consciousness, as the present consciousness observes its past by means of the false ideas. And as a medium of difference the false idea allows for the production of a present consciousness that differs from the past. In this sense, Moritz speaks of childhood ideas as the "ribbon" between the two: "Could it be that the ideas from childhood are the thin and imperceptible ribbon that connects our present state with the past state, when that which constitutes our self now at one time was present under different circumstances?" ("E," p. 66). ${ }^{29}$ Without false ideas, the present self would be incapable of knowing its past, and it would not be able to differentiate itself vis-à-vis its past.

Moritz's own life-or is it Anton Reiser's? - is the testing ground for this "revisionist" recollection model, and it would be tempting at this point to engage in a reading of Anton Reiser in this vein. However, I will focus on

29. There are many indications in these texts that the notion of idea is to be taken as a sensual, or conceptual, representation of how things are, as a medium of presentation, rather than as a neo-Platonic, detached, and abstract idea. For a fuller reading of this quote, see Anthony Krupp, "Other Relations." 
just one moment in the life of Anton Reiser, which shows the potential of Moritz's insights. This moment is depicted as a turning point in the novel's third book, in which Reiser finds a solution to his permanent crisis. This is also the part of the novel where Moritz first employs "the self" ("das Selbst") as a term to describe Reiser's state. The occasion of this epoch in young Reiser's life is a public school examination in which he is never asked a question because his clothing marks him as poorer than his peers. He leaves the scene while the examinations continue, goes for a walk, and has the following insight:

Where was he to find firm rooting in the great empty world, where he saw himself pushed out [herausgedrängt] from all human relations?... The thought came to him that from childhood on his fate had been to be suppressed [verdrängtzu werden]. If he wanted to look on at anything, when it was a case of pressing oneself forward [sich hinzuzudrängen], everyone else was quicker and pressed themselves [drängte sich vor] in front of him.... And he retired, and now was looking at the throng [Gedränge] from a distance, as he stood there, lonely.... The thought that he could look at the throng so quietly without mingling in it, made up somewhat for the loss of what he missed seeing: alone, he felt himself nobler and more distinguished than as someone lost in the crowd. His pride, which came to the fore, overcame the vexation that he felt at first. That he could not join the crowd pressed him back into himself [daß er an den Haufen sich nicht anschließen konnte, drängte ihn in sich selbst zurück]; and ennobled and exalted his thoughts and feelings.... This solitary walk developed in him, in a moment, more feelings and contributed more to his spiritual education than all the lessons he had ever had in school. ... It was this solitary walk, which raised Reiser's self-esteem [Selbstgefühl], widened his horizon, and gave him a clear idea of his own isolated existence. ${ }^{30}$

This is a seminal psychological moment, at least as regards the psychology that Moritz develops. In articulating his sudden understanding that he has been suppressed (see his constant use of inflections of the German drang/drängen), Reiser adopts the activity of repression upon himself and begins to actively suppress himself: "that he could not join the crowd pressed him back into himself." What happens here is that Reiser appropriates the impression of repression (to be pushed aside, pressed out of the way, and so on) in order to correct this very impression (namely, by "press- 
ing" himself into himself). He reenacts his own repression, only this time he is the agent and the object. Instead of simply being (sup- or im-) pressed, he presses himself into himself. The duplication of the act opens up a duality of subject and object, of the prior victim of a repression and its agent, of that which is (sup)pressed and that which (sup)presses, and thus of the weakness of the past and the strength of the present.

It is important to emphasize that this therapeutic act is not simply an undoing of the past but rather a preservation and repetition of the wound. At the same time the later repression is not merely a repetition of past events, but also a grammatical turn from the passivity of being suppressed to the activity of actively suppressing, a reduplication that he controls. He makes the original act his own; he makes it himself. The weapon that inflicted the wound becomes an integral part of the healing process. The past impression is literally the material of its own amelioration. The self becomes the frame within which the repetition and reversal of the past takes place.

As long as Reiser was simply suppressed by other people, he was merely the fluctuating, impulsive receiver of acts over which he had no command. But once he controls the repression and duplicates it by suppressing himself, the scene of suppressing and being suppressed becomes the operative site where he "takes place," where his being is invoked, and where he is "ennobled." The past wounding becomes an operational space where the infliction is staged and restaged. This restaging implies the stability of a theatre of the self within which the wounding is presented. Around the suppressed being is the stable frame of someone who monitors and repeats the past of repression.

What Moritz demonstrates is that the past can be repeated, not in the sense of an identical reiteration of a recorded message, but, rather, as a stage script that one can employ to act out. As a script, the past can be followed to the letter, repeated in that sense. And, at the same time, everything is different about this repeated past because it is directed, staged, manageable-an orchestrated disaster. It takes place as repetition on some stage within a frame, a stable architecture, within the walls of some laboratory, operating room, or test chamber. Only within a set observatory can two acts appear to be identical. Thus, the repetition of the past that Moritz enacts here and elsewhere both requires and posits the stability of a perspective from which two acts or two situations can be-or appear to be-identical. For this new being, everything can be repeated, restaged, reenacted. Repeatability is the essence of the self.

Before this epoch in Anton Reiser's journey through life, no such stable entity existed. His identity was in flux. However, in the moment of the 
quoted scene of reversal, the stability of a fixed perspective comes about: the stability of Reiser's recognition of being the one who has been suppressed. And, with this moment, Moritz has a self, an identity. ${ }^{31}$

Precisely because of this duality within himself and the split between subject and object, Reiser can be the addressee of his own acts, be his own goal and complete in himself (as Moritz would say, in sich selbst vollendet) because his operations have himself as an object. The resulting effect is the solidification of the self, the institutionalization of the self as an entity that perpetuates itself through its acts because its acts are aimed at itself as the telos. ${ }^{32}$ In this sense we could say that the new self is above all an institution that serves no other purpose than guarding its self-identity. Thus, the reduplication and the correction of past impressions is the force that makes the affectable individual unaffectable and makes him or her a "fortress," as Moritz writes elsewhere. ${ }^{33}$ Indeed, Moritz-who is usually hailed as the inventor of the autonomy of the artwork-could also claim to be the coinventor, along with Rousseau, of the autonomous self that is complete in itself like a work of art. ${ }^{34}$

This is the remarkable foundational act of psychology: that which wounds the individual can - but there is no guarantee-turn out to be his greatest strength, can be his shell of protection once it enters the apparatus of recollection..$^{35}$ For Moritz, the past that shapes an individual is the very

31. Laurie Ruth Johnson reports how Moritz transforms wounds and pain into a solid aesthetic form. Whereas Moritz believes pain to resist representation, it is nevertheless the foundation of aesthetic stability as Moritz shows in his retelling of the Philomena story; see Laurie Ruth Johnson, The Art of Recollection in Jena Romanticism: Memory, History, Fiction, and Fragmentation in Texts by Friedrich Schlegel and Novalis (Tübingen, 2002), pp. 78-85.

32. It makes sense here to consider that Moritz is not only one of the fathers of empirical psychology but also the inventor of the "autonomy of art." Since his 1785 texts, Moritz conceptualized art according to an institutional model, making it complete in itself. It has already been shown how Moritz's theory of autonomous art carried over into other areas of his thought, such as politics. See Jonathan M. Hess, Reconstituting the Body Politic: Enlightenment, Public Culture, and the Invention of Aesthetic Autonomy (Detroit, 1999).

33. It is crucial for man "that his own thinking self does not present any contact with misfortune, so that misfortune can only play with the self's environment but not affect the self in itself; so that the self is able — in every moment of its existence — to withdraw into itself and freely give over everything surrounding it to contingency-... from within this secure fortification that I have drawn around myself, I view contingency with contempt" (Moritz, "Denkwürdigkeiten, aufgezeichnet zur Beförderung des Edlen und Schönen," Werke, 3: 214).

34. Of course, readers of Moritz's aesthetics will be quick to add that this autonomy does not exist and is only rhetorically simulated. See Rüdiger Campe, "Zeugen und Fortzeugen in Karl Philipp Moritz Über die bildende Nachahmung des Schönen," in Kunst—Zeugung—Geburt: Theorien und Metaphern ästhetischer Produktion in der Neuzeit, ed. Christian Begemann and David E. Wellbery (Freiburg, 2002), pp. 225-50.

35. In this sense, Derrida can speak of the archive as both a place of the beginnings, of the past, the foundation, and as the place of command, control, and power. See Derrida, Archive Fever. Using this notion, we could say that Moritz discovers the self as archive. Moreover, Moritz is the 
obstacle to be overcome, the material for a renewal, and that which provides for the very operation of the renewal of the individual. ${ }^{36}$

Thus, the starting point of pedagogy and psychology alike is that the past shapes the identity of an individual. However, what psychology adds to pedagogy is that the past shaping of the individual can be reversed by certain acts of recollection. Weakening acts can be turned into a source of strength. In short, the pedagogical subject can be improved, bettered, or spoiled, whereas the psychological self comes about by being changed, inverted, or dissociated from itself. The self as such is the product of the operation of the psychological, the correction of memory, the archival act. It is in this sense that psychology is not a science of understanding but a technique.

\section{Hoffmann and the Self as Prison}

Moritz's discovery of the force of recollection starts the age of the Bildungsroman. Moritz's friend Goethe offers the paradigmatic example, Wilhelm Meisters Lehrjahre, just a few years later. Still, Moritz's careful optimism about the force of recollection is not universally shared. For Moritz, the reversal and consequent institutionalization of the self allows the individual to stand its ground against its environment and be strong. The new self is better, that is, better protected from the outside throng. However, its demise is at hand. The new operations that Moritz discovers, namely the grammatical turn of the self, can also, with only a few alterations, lead to the individual's imprisonment behind the bars of the self.

The self as a prison: This, at least, is the lesson of Hoffmann's signature novella Fräulein von Scuderi (1818), a story usually hailed as the world's first detective story with a Miss Marple-type detective. ${ }^{37}$ In this novella, a famous goldsmith confesses that he killed his clients to regain the precious stones they had given him for improvements. He claims that his drive to kill and to steal stones finds its origin in a primary event experienced by his mother while she was pregnant with him:

Wise men often speak of the strange impressions which afflict pregnant women, and of the strange influence these impressions from the outside

thinker of archival production, the one who discovers how recollection establishes the stable structure of an institution that reverses the weakness of the individual into a source of strength.

36. Although I will not go down this road now, it seems fair to mention that the other and most discredited founder of psychology, Franz Anton Mesmer, shares Moritz's willingness to abandon full knowledge of the self in order instead to focus on the reversal. In a witty account of the birth of empirical psychology, Peter Sloterdijk characterizes the task of psychology as a cure from the self; see Peter Sloterdijk, Der Zauberbaum: Die Entstehung der Psychoanalyse im Jahr 1785 (Frankfurt, 1985).

37. For a more complex account, see Edgar Marsch, Die Kriminalerzählung: Theorie-GeschichteAnalyse (Munich, 1972). 
can have on a child. I have been told a strange story about my mother. In the first month in which she was pregnant with me, she was watching a brilliant court festival in the Trianon. There, her glance fell on a cavalier in Spanish dress, with a glittering bejeweled chain about his neck from which she could scarcely tear her eyes away. Her whole being lusted after the sparkling stones.... The cavalier noticed my mother's longing, fiery glances.... He found a way of approaching her, of enticing her away to a lonely place. There he clasped her passionately in his arms; my mother grasped the beautiful chain, but at the same instant he fell and dragged my mother with him to the ground. Whether it was sudden heart attack or some other cause-suffice is to say that he was dead. My mother's efforts to free herself from the stiffened arms of the corpse were vain. His hollow eyes, their sight extinguished, fixed upon her, the dead man rolled to the ground with her.... The horror of this threw my mother on to a sick-bed. ... She recovered. ... But the fear of the terrible moment had gone into me. My evil star had risen and had sent down fires which kindled in me one of the strangest and most pernicious of passions. Even when I was very young, sparkling diamonds, golden jewelry, meant more to me than anything else. ... It was only so as to be able to handle gold and precious stones that I turned to the goldsmith's trade... As soon as I had completed a piece of work and delivered it, I became agitated, I fell into a state of desperation which robbed me of my sleep, my health-my vital energies. The person for whom I was working stood before my eyes day and night like a ghost, adorned with my jewelry, and a voice whispered in my ear: It is yours really, it is yours really; take it, then—what do diamonds mean to a dead man?38

What this text spells out are the effects of having a primal scene for one's life. The primal scene maps out the territory within which the self will exist. All later life affirms the earlier scene in the form of repetitions and displacements. However, precisely because there is such a primal scene-namely, the mother's arrest in the stiffened arms of the cavalier - the later repetitions differ from it in at least one respect. The mere temporality of the primal scene, of the mother first longing for the stones and, then, the sudden death of the cavalier, is reduplicated, repeated, and reversed as a causality. The owner of the stones is already dead because there is the longing, because there is a stone. Whereas the primal scene contained no causal and only an accidental, or temporal-situational, connection between the mother grasp-

38. E. T. A. Hoffmann, "Mademoiselle de Scudery," trans. Sally Hayward, Tales of Hoffmann, ed. R. J. Hollingdale (London, 1982), pp. 64-65. 
ing the precious jewels and the death of their owner, the repetitions by the son imply a causal connection between the stones and the death of the owner. The primal scene has become a script, mold, or law for all later repetitions. Cardillac hears the whispering voice in his ear saying that the bearer of stones is already dead, while he is still alive: "What do diamonds mean to a dead man?" Apparently, the voice anticipates the repetition of the primal scene, that is, views it as a given fact to the degree that the one who has the stones automatically will be, is, has been, and has to be the dead man. The command of the inner voice is so strong that the one who listens to it has to transform the scene in order to make it fit the scene that the voice from the past indicates, which means the owner must be killed. Put simply, the repetition of a primal scene excludes time and replaces it by mere necessity. The temporal lineage of the primal scene initiates and becomes a causal order. ${ }^{39}$

Thus, the mother, in the state of fixation, enveloped by the corpse, becomes the model for the self in general. It is the stability of the envelopment—of the incarceration — that provides the individual's identity. ${ }^{40} \mathrm{An}$ identity, a self, comes about once there is a state of fixation that provides a space within which repetition is possible. The first experience of such a fixation serves as the model of the self, be it the horrific scene for Cardillac's mother or the merely unpleasant experience of Hoffmann's own pregnant mother, traveling and thus locked up in noisy horse carriages, an experience that Hoffmann blames for his later restlessness. In other words, repetition compulsion (Wiederholungszwang) is not an arbitrary law imposed upon individuals by some prehuman history as Freud contemplated but rather is a structural necessity for having a self.

39. Burkhard Dohm suggests the shaping of Cardillac's identity be considered in terms of the prenatal unity of mother and child, a motif that Lessing had already used in Laokoon. Indeed, as Dohm shows, several key theories of the era stressed such a prenatal unity, as found in Mesmer's hypnotism and Gotthilf Heinrich Schubert's psychology. Unfortunately, Dohm does not use these sources to make a critical comparison of early psychology with Hoffmann's ideas. Instead, Dohm seems to fill the (fascinating) voids of the novella with contemporary science; see Burkhard Dohm, "Das unwahrscheinliche Wahrscheinliche: Zur Plausibilisierung des Wunderbaren in E. T. A. Hoffmanns Das Fräulein von Scuderi," Deutsche Vierteljahrsschrift für Literaturwissenschaft und Geistesgeschichte 73 (June 1999): 289-318.

40. In Achim Würker's reading of the novella, he goes so far as to argue that the story manifests a longing for the prenatal state of being in the mother's womb. Würker also suggests that the jewels in their cases serve as a representation (we may say allegory) of this longing. Würker's unorthodox approach of noticing the story's effects on him, the reader, is certainly philologically suspect. And, indeed, some of his ideas lack the proper grounding of textual evidence (for example, Würker suggests that the prenatal Cardillac witnesses the sexual act of his parents and reacts with delayed aggression). However, it should be noted that there are quite a few readings of the story that succeed in integrating as many of the text's bizzare details as Würker's. See Achim Würker, "Der Umgang mit dem Geheimnis: Unbewußte Lebensentwürfe in E. T. A. Hoffmann's 'Das Fräulein von Scuderi,'” Jahrbuch für internationale Germanistik 27, no. 2 (1995): 107-41. 
There are obvious differences in the structure and vocabulary in Moritz's and Hoffmann's accounts of the formation of the self by means of repetition. For one, Moritz relies on an active process of cognition in his correction/reversal of memories. Hoffmann's novella, on the other hand, indicates that there is no possibility of a corrective impetus for setting up a mechanism of reversal. Once the scene of arrest serves as the primal scene, it becomes the law of all repetition. This leads to a second fundamental difference. In Moritz's accounts, the repetitions serve a particular goal, namely, to free the individual from the negativity of the past. In Hoffmann, however, there is no implicit teleology in the repetitions. The repetitions occur for their own sake, and the individual is doomed to follow them. Thirdly, these differences expand the idea of what qualifies as a primal scene. In Moritz's texts, any false idea that calls for correction will set up a space for repetition because these moments provide later memory with a function-namely, to correct. In Hoffmann's texts, however, any scene involving an arrest is potentially the once-and-forever site of the self. ${ }^{41}$

Nevertheless, the basic similarity between Moritz and Hoffmann should not be overlooked. First of all, both accounts rely on a mechanism of repetition of the past to consolidate a self. The very space of the self, that is, the self as such, is mapped out in the territory covered by the repetitions. Selfhood consists in the stability necessary to perform the operation of repetition (which in both cases involves a particular reversal). Secondly, in both cases the repetition transforms the passive first act into an activity by the subject; Reiser suppresses himself, and Cardillac kills the owner of the stones. Thirdly, in both cases the repetition involves a linguistic dimension that indicates that the self is essentially linguistic. In Moritz's case, this includes both the grammatical turn from passive to active, as well as the frequent stressing of linguistic phenomena that need correction, such as with young Reiser's mistaken memory of alliteration in the gospels. In Hoffmann's account, the strong impression of the sparkling stones lives on in the son and is transformed metonymically in several steps from the "sparkling stones," to the shining eyes and the "hollow eyes," and then, finally, to the "evil star" that whispers into the goldsmith's ear that he should kill and take control of the stones.

In short, while Moritz and Hoffmann fundamentally differ in their evaluations of repetition as potentially positive or as purely negative, they both rely on repetition as the place where the self becomes itself.. ${ }^{42}$

41. Jürgen Fohrmann has argued that the new idea of the curriculum vitae around 1800 reflects an awareness of the narrative command one has over one's past. Any single moment can be chosen as a point of culmination and climax for relating one's life. See Jürgen Fohrmann, "Einleitung," in Lebensläufe um 180o, ed. Fohrmann (Stuttgart, 1999), pp. 1-15.

42. The middle-class man's project to elevate himself from the state of weakness by means of the psychological enthrones a new master and builds a new prison for the middle-class man. If we 


\section{Balzac's Cure of Trauma: Woman as Laboratory Animal}

The technology of reversal is at the center of other early trauma texts as well. Fifty years before Charcot's attempts to heal trauma by means of hypnosis, in Balzac's novella Adieu (1830) a whole battle scene from the Napoleonic winter war in Russia is restaged in order to reverse a young woman's loss of sanity. In the battle, hardly conscious of anything around her, she departs from a lover who does not yet know that he loves her with the word "Adieu." This very word is the last human trace that remains of her in the years that follow, in which she first becomes a plaything for the soldiers and then an animal-like creature living in an abandoned villa. And, when her lover-to-be, the officer, finds her again, she still does not return to a human consciousness. However, he now views their separation as the beginning of a love to come. This is why he resorts to his plan to restage the complete battle scene with the help of hundreds of hired peasants. He wants to rethread her human life where it ended, to bring it back on track. Indeed, the rebooting works. For a moment, she seems to come back to consciousness with all memories intact. However, the situation overwhelms her, again, and she dies in the arms of the officer. She is made to be the laboratory animal. The experiment succeeds, and she dies.

Here, again, we are dealing with repetition. This time, the repetition does not take place within an institutionalized self (that is, a self institutionalized by means of repetition) but relies on a different framing stabilizer: the situation, the battle scene that frames the repetition. ${ }^{43}$ Again, the very repetition involves a reversal that rotates on an axis of stability. This axis is the word adieu, the title of the story. In the primal scene in the winter battle, adieu was a word of departure. Little hope remained for a later reunion between the two because the officer's situation appeared hopeless. The word is all that is left for her during the years of her derangement. Even when the situation is repeated in every detail, there remains the word of departure, and thus the situation remains one of departure. And, even when her lover, the officer, returns, the very word adieu that she utters overshadows the repetition. It must again be a scene of departure because the word of departure, adieu, is repeated. And, because he arrives, she leaves. She dies. Again, the repetition is a full repetition only because it is a reversal of the primary scene: Where she was saved before, she now dies. At the same time, this reversal stabilizes the primary scene by making the temporality of de-

were to follow Friedrich Kittler's reading of this story, we would have to say that this new master, who takes over the place of the (dead) aristocrat, is a mistress, that is, the mother. See Friedrich Kittler, Dichter, Mutter, Kind (Munich, 1991).

43. It is useful to consider the historical background of this spectacle for a full reading of the text; see Maurice Samuels, "Realizing the Past: History and Spectacle in Balzac's Adieu," Representations, no. 79 (Aug. 2002): 82-99. 
parture its law. The officer will not forget her and later commits suicide in remembrance of her.

In a departure from Moritz's psychology, the officer in the novella tests a complete undoing of trauma using repetition as the instrument of the undoing. However, the officer's failure is described by a logic close to that of Moritz. Where there is a stable frame of repetition, a reversal will occur that also reduplicates the original. An adieu is still an adieu. The repetition-which is the only chance for a cure, a cure that the woman does not ask for, as Shoshana Felman emphasizes-can only occur by simultaneously affirming the stability of the frame, the situation, the adieu, which means the departure. ${ }^{44}$ The first attempt at undoing trauma, as exemplified in this story, is thus already a catastrophe. One can instrumentalize trauma only by traumatizing the instrument.

\section{Moritz versus Freud: Trauma and Ideology}

When we read about trauma today, one thing seems clear: trauma and the self cannot be thought together. Trauma is the wound that prevents the self from being a self. The self cannot integrate trauma into itself. Trauma is not a mere wound somewhere that can be healed or left alone. Trauma, rather, consumes the self. The trauma of trauma, it seems, is that it does not have a beginning or end, no space from here to there, no time of before and after, and thus cannot allow any discourse that might address trauma. Trauma is a memory disorder that prevents the wounding from being properly stored as a past event; it hangs on, is everywhere and nowhere. Trauma limits the self to a traumatic space of repetition without borders and contours. Thus, trauma does not even limit the self to a space because trauma does not permit space. Where there is trauma there is no space, and no space for the self. Trauma is the end of the self. Thus, trauma does not even offer the end of the self because there is not even time for an end.

However, what we have just read about early empirical psychology points in the opposite direction. For thinkers like Moritz, trauma, that is, voluntary or involuntary repetition of the past, is the condition of the possibility of the self. In fact, the repetition itself is the very force that implies the stability of a self and will posit a self even if such a thing is not yet available. Trauma and self are flipsides of one and the same coin.

The contrast between early and contemporary forms of trauma studies is obvious, as it is obvious that much of this contrast is owed to differing

44. Using the novella's politics of gender division and animality as the starting point, Felman's famous reading questions (the equation of) madness, animality, and silence of the woman; see Shoshana Felman, Writing and Madness: Literature/Philosophy/Psychoanalysis, trans. Martha Noel Evans (Ithaca, N.Y., 1985). 
notions of selfhood. For Moritz, the self is an entity to be constructed; for Freud it is a hidden reality to be discovered and set free. To mark the contrast between eighteenth- and twentieth-century thought on trauma, one can examine how Freud dissociates two terms that Moritz presents as one: remembering [erinnern] and repeating [wiederholen]. In his 1913 text "Remembering, Repeating, and Working-Through," Freud separates the two to such a degree that each stands for a different relationship to the past. ${ }^{45}$ Freud calls Erinnern the exceptional direct access to the past, whether it is simply not blocked by anything or opened up by means of hypnosis. On the other hand, he calls Wiederholen the repeating of the past in such a way that the repeating subject does not know that he or she is repeating some past event (usually, the repetition occurs partly displaced and involves some Übertragung). The key advancement that leads Freud to this splitting of both notions is, of course, his positing of repression (Verdrängung). The troubling past usually cannot be remembered (erinnert) because it is repressed (verdrängt). Thus, for Freud the work of healing is mostly a work of undoing repression, that is, to actively combat and overcome (überwinden) the resistance of repression. Put simply, the work of therapy is to transform repetition into remembrance. One is oneself once one is able to let go of the (traumatic) past. Trauma and repression are the forces that hinder one from being oneself.

For Moritz, therapy goes in the opposite direction. The task is to appropriate the (remembered) past by means of repeating it. The work of therapy is to transform mere remberence into repetition. Repetition, as Moritz sees it, is thus not only an act of affirming the past but also of reversing the passivity of the past into activity. This includes, as we have seen, not an overcoming of repression, but rather an active repeating, evoking, stimulating, instituting, and operating of repression. One is the repressor of oneself, the repressed. Trauma (that is, repetition) is what enables one to become oneself.

According to Freud, repression is the subject's emergency strategy. According to Moritz, repression is the enemy that is to be converted by the subject into a tool. Labor, be it the labor of appropriating repression as in Moritz or the labor of battling repression as in Freud, is the common denominator of their respective therapies.

What Moritz adds to Freud is a positive account of the institutionalization involved in traumatic repetition. The space of repetition is the space

45. See Sigmund Freud, "Remembering, Repeating, and Working-Through (Further Recommendations on the Technique of Psycho-Analysis)" (1914), The Standard Edition of the Complete Psychological Works of Sigmund Freud, trans. and ed. James Strachey, 24 vols. (London, 1958-74), 12:145-56. 
of the self's insistence and thus existence. Where Freud sees it as his goal to crack down on the resistance surrounding repression, repetition, and trauma, Moritz would view this as an attack on the self. Freud, in fact, frequently records that this is how his patients experience his therapy-as an attack against their essence, against themselves. For Moritz, even the horror of the past can be a home for the self. Repetition of the past is not simply the vocabulary of trauma and repression [Verdrängung] but of a fortress of selfhood.

Still, Moritz sees reason to leave trauma and repetition behind. He does so, however, not in the name of the self. Rather, the self, a self, is the very thing to be left behind. The goal is not to find a new snail shell. Instead, it is to go into an open land. This is accomplished not through Freudian therapeutic attacks (even if these attacks are in the service of some hermeneutics) but rather by means of the lure of the unknown, of that which is not known or knowable. It is poetry and promises of another world that prompt Moritz to go elsewhere. Precisely because repetition and trauma mark the space of the self, it is the unrepeatable, the singular, or unknown that become destinations for the individual. From Moritz's perspective Freud forgets to offer his patients a reason for leaving the fortress of trauma. For Moritz, there is still a beyond to psychology, even within a psychological novel. ${ }^{46}$

\section{Outlook: Trauma Studies Today}

Let me close by considering two of the potential abuses of the notion or technology of trauma. First, like any concept, the concept of trauma is not a description of a truth but a formative principle that makes truth. As a changing historical concept, trauma has served various interests and filled various functions over the past two centuries, some of which have been sketched in this essay. The point of offering an historical account is not to invalidate trauma but rather to indicate in which way a specific understanding of trauma shapes the way a case of trauma will be experienced, told, understood, and used. And, of course, whenever experience is ruled by a concept, ideology is a possibility. Even empirical psychology can be a blind

46. More recently, a third model for the relationship between self and trauma has been suggested: to understand and accept the traumatized being as a "diminished self" (Lawrence Langer, Holocaust Testimonies: The Ruins of Memory [New Haven, Conn., 1991], p. 177). This third model has been proposed by Jean-François Lyotard, who understands trauma to be the only, paradoxical access to certain historic experiences, such as the Holocaust; see Jean-François Lyotard, Heidegger and "the Jews," trans. Andreas Michel and Mark S. Roberts (Minneapolis, 1990). In a related way, Michael S. Roth emphasizes that the so-called healing of trauma normalizes and banalizes the past at the cost of its uniqueness. Thus, he highlights attempts to accept the past as an open wound; see Michael S. Roth, "Hysterical Remembering," Modernism/ Modernity 3 (Apr. 1996): 1-30. 
science that applies its preconceived notions instead of observing. Other forums like the popular media are even more likely to simply apply a notion such as trauma. ${ }^{47}$ When it was pointed out to him that the phenomena did not fit one of his general concepts, Hegel is supposed to have said: "So much worse for the phenomena."

Secondly, what Moritz indicates to us is that despite everything even a terrible wound can potentially, but by no means necessarily, become a source of strength for the survivor. As a technology of reversal, trauma converts accounts of certain horrors into strengths. This means it is structurally not necessary that the trauma is one's own or is authentic. Fabricating one's traumatic past or speaking on behalf of another's trauma can have the same strengthening effect as "real" trauma, especially because trauma today serves as the icon of authenticity. Put differently, evoking the speech of trauma harbors a promise for those who speak of it: selfinstitutionalization. And that is precisely why this form of speech ought to be reserved for the victim. Otherwise, the temptation for those who speak on behalf of the victim to gain that momentum of self-institutionalization and thus to take it away from the victim will be enormous, probably irresistible.

Whoever speaks of someone else's trauma walks a thin line between supporting the weak, giving them a voice, and infantilizing the weak, stealing their right to speak and thus disempowering them where there is a chance for self-empowerment. ${ }^{48}$ Any power, whether institutional, legal, academic, professional, therapeutic, political, psychological or linguistic, ought to be reserved for those whose trauma is at issue. To be sure, it would be worse not to speak of suffering. The witness, the friend, the helper, the advocate can and should talk about what they have witnessed; trauma itself one cannot witness. There is indeed an ethics of trauma. It is that of noninstitutionalization. The constant inherent danger in trauma studies is that it institutionalizes and strengthens itself at the cost of those whose care has been entrusted to it and who thus lose the ability to strengthen themselves.

47. One can make the case that this is exactly what happened after September 11, 2001. The media, in search for a fitting narrative, resorted to trauma stories. This may have been well founded in regard to the families of victims but failed to consider the political dimensions of the events by representing the country as an unconscious victim; see Fritz Breithaupt, "Rituals of Trauma: How the Media Fabricated 9/11," in Media Representations of September 11, ed. Steven Chermak, Frankie Y. Bailey, and Michelle Brown (Westport, Conn., 2003), pp. 67-81.

48. In Dominick LaCapra's terms, one could say that the stealing of speech of the victim and thereby from the victim is parallel to the move from "loss" to "absence" for the victim. Once someone else uses the language of trauma, the speech cements the wound, the loss, converts it to a fact, a permanent absence. LaCapra writes: "When loss is converted into (or encrypted in an indiscriminately generalized rhetoric of) absence, one faces the impasse of endless melancholy, impossible mourning, and indeterminable aporia in which any process of working through the past and its historical losses is foreclosed or prematurely aborted” (Dominick LaCapra, "Trauma, Absence, Loss," Critical Inquiry 25 [Summer 1999]: 698). 